\title{
PENDAMPINGAN ANAK BERHADAPAN DENGAN HUKUM
}

Oleh:

Dimas Bagus Hari Satrio, Budi M. Taftazani, \& Herry Wibowo

\begin{abstract}
ABSTRAK
Setiap tahun, terjadi 4.000 kasus pelanggaran hukum yang dilakukan oleh anak. Menurut Romli, Atmasasmita dalam Wagiati Soetodjo, terdapat faktor intrinsik dan ekstrintik dari kenakalan anak yang menyebabkan anak melakukan tindak pidana dan terpaksa berhadapan dengan hukum, faktor intelegentia, usia, kelamin, dan kedudukan anak dalam keluarga menjadi faktor instrinsik kenakalan anak dan faktor rumah tangga, pendidikan \& sekolah, pergaulan anak, dan mass media menjadi faktor ekstrinsik kenakalan anak. Undang-undang perlindungan anak tidak menjamin anak berhadapan dengan hukum mendapatkan hak-hak yang seharusnya mereka peroleh. Pekerja sosial sebagai pendamping anak berhadapan dengan hukum harus memiliki pribadi matang, kepekaan, kreatif , pengamatan diri, keinginan menolong, keberanian, dan kepekaan. Rekomendasi yang diajukan : (1) Peningkatan kualitas sumber daya manusia (SDM) pekerja sosial melalui Diklat pekerja sosial koreksional, (2) menguji coba model pendampingan pada anak berkonflik hukum, (3) advokasi pemerintah tentang batas usia minimal anak berkonflik hukum dari 8 tahun menjadi 12 tahun. Kata Kunci: Anak berhadapan dengan hukum, Pekerja sosial, Perlindungan Anak.
\end{abstract}

\section{PENDAHULUAN}

Maraknya kasus anak yang melakukan tindakan kejahatan semakin sering terjadi. Sering terdengar berita tentang anak dibawah umur melakukan tindak kriminal. Data BPS (2003) menyebutkan bahwa setiap tahun, terjadi 4.000 kasus pelanggaran hukum yang di lakukan oleh anak. Sebanyak 3.722 anak tersebar di 14 Lembaga Pemasyarakatan Anak (LP Anak). Terbatasnya jumlah LP Anak, memberikan peluang anak berkonflik hukum berada di LP Dewasa dan Pemuda. Sementara, tindak kekerasan pada anak selama proses penyidikan maupun di LP masih banyak terjadi. Anak diinterogasi seperti lazimnya pada orang dewasa. Anak berkonflik dengan hukum sering tidak mendapat perlindungan yang wajar, dan tanpa bantuan hukum.

Lembaga Advokasi Hak Anak (LAHA) Bandung (2004) menemukan berbagai pelanggaran hak anak, seperti anak tidak didampingi penasihat hukum pada tahap penyidikan dan proses penuntutan. Kondisi tersebut memberikan gambaran bahwa telah terjadi pelanggaran hak-hak anak berkonflik hukum seperti yang sudah diatur dalam UU No. 3/1997 tentang Pengadilan Anak, UU No. 23/2002 tentang Perlindungan Anak serta tidak sejalan dengan Konvensi Hak Anak, yang mengkatagorikan anak berkonflik hukum sebagai anak yang membutuhkan perlindungan khusus, yang terkandung didalamnya yaitu prinsip partisipatif, tumbuh-kembang, nondiskriminatif, dan prinsip kepentingan terbaik bagi anak.

\section{Pengertian Anak}

Di Indonesia peraturan perundang-undangan yang mengatur tentang anak tertuang pada Undang-Undang No. 11 Tahun 2012 tentang Sistem Peradilan Pidana Anak, Undang-Undang Nomor 4 tentang Kesejahteraan Anak, Undang-Undang Nomor 39 Tahun 1999 Hak Asasi Manusia, Undang- 
Undang Nomor 23 Tahun 2002 tentang Perlindungan Anak dan Berbagai peraturan lain yang berkaitan dengan masalah anak.

Pengertian anak berdasarkan Pasal 1 butir 1 Undang-Undang Nomor 23 Tahun 2002 tentang Perlindungan Anak yaitu : "Anak adalah seseorang yang belum berusia 18 (delapan belas tahun; termasuk anak yang masih dalam kandungan".

Sedangkan pasal 1 ayat (3) UU No. 11 Tahun 2012 tentang Sistem Peradilan Pidana Anak juga menjelaskan tentang anak yang berkonflik dengan hukum:

"Anak yang berkonflik dengan hukum yang selanjutnya disebut Anak adalah anak yang telah berumur 12 (dua belas) tahun, tetapi belum berumur 18 (delapan belas) tahun yang diduga melakukan tindak pidana"

Pengertian anak juga terdapat pada Pasal 1 Convention On The Rights of The Child, anak diartikan sebagai setiap orang dibawah usia 18 tahun, kecuali berdasarkan hukum yang berlaku terhadap anak, kedewasaan telah diperoleh sebelumnya.

Beberapa negara juga memberikan definisi seseorang dikatakan anak atau dewasa dilihat dari umur dan aktifitas atau kemampuan berpikirnya. Di negara Inggris, pertanggungjawaban pidana diberikan kepada anak berusia 10 (sepuluh) tahun tetapi tidak untuk keikutsertaan dalam politik. Anak baru dapat ikut atau mempunyai hak politik apabila telah berusia diatas 18 (delapan belas) tahun.

\section{Perlindungan Anak}

Setiap anak juga memiliki perlindungan yang tertuang pada pasal 1 dan 2 Undang-Undang Perlindungan Anak menentukan bahwa perlindungan anak adalah segala kegiatan untuk menjamin dan melindungi anak dan hak-haknya agar dapat hidup tumbuh, berkembang dan berpartisipasi secara optimal sesuai dengan harkat dan martabat kemanusiaan, serta mendapat perlindungan dari kekerasan dan diskriminasi. Undang-Undang Perlindungan anak mengatur tentang asas dan tujuan perlindungan anak tertuang pada pasal 2 dan pasal 3, sebagai berikut:

Pasal 2: penyelenggara perlindungan anak berasaskan Pancasila dan berlandaskan UndangUndang Dasar Negara Republik Indonesia Tahun 1945 serta prinsip-prinsip dasar konvensi hak anak meliputi:

1. Non diskriminasi

2. Kepentingan yang terbaik bagi anak

3. Hak untuk hidup, kelangsungan hidup, dan perkembangan

4. Penghargaan terhadap anak

Pasal 3: Perlindungan terhadap anak yang bertujuan untuk menjamin terpenuhinya hak-hak anak agar dapat hidup, tumbuh, berkembang, dan berpartisipasi secara optimal sesuai dengan harkat martabat manusia, serta mendapat perlindungan dari kekerasan dan diskriminasi demi terwujudnya anak Indonesia yang berkualitas, berakhlak, mulia, dan sejahtera.

Pasal 2 huruf e Undang-Undang tentang Perlindungan Anak menegaskan hak untuk hidup, kelangsungan hidup, dan perkembangan merupakan hak asasi yang paling mendasar bagi anak yang dilindungi oleh Negara, pemerintah, keluarga, orang tua, sekaligus merupakan hak setiap manusia yang paling asasi.

Perlindungan anak diusahakan oleh setiap orang, orang tua, keluarga, masyarakat, pemerintah maupun Negara. Pasal 20 Undang-Undang Perlindungan anak menentukan: "Negara, pemerintah, masyarakat, keluarga, dan orang tua berkewajiban dan bertanggungjawab terhadap penyelenggaraan perlindungan anak."

Kewajiban dan tanggung jawab Negara dan Pemerintah dalam usaha perlindungan anak diatur dalam Undang-Undang Perlindungan Anak yaitu: 
1. Menghormati dan menjamin hak asasi setiap anak tanpa membedakan suku, agama, ras, golongan, jenis kelamin,etnik, budaya, dan bahasa, status hukum anak, urutan kelahiran anak dan kondisi fisik dan/atau mental (Pasal 21);

2. Memberikan dukungan sarana dan prasarana dalam penyelenggaraan perlindungan anak (Pasal 22);

3. Menjamin perlindungan, pemeliharaan, dan kesejahteraan anak dengan memperhatikan hak dan kewajiban orang tua, wali, atau orang lain yang secara umum bertanggung jawab terhadap anak dan mengawasi penyelenggaraan perlindungan anak (Pasal 23);

4. Menjamin anak untuk mempergunakan haknya dalam menyampaikan pendapat sesuai dengan usia dan tingkat kecerdasan anak (Pasal 24)

\section{Anak Berhadapan Dengan Hukum}

Berdasarkan Pasal 1 ayat (2) UU No. 11 Tahun 2012 tentang Sistem Peradilan Pidana Anak, yang dimaksud dengan anak yang berhadapan dengan hukum (children in conflict with the law), adalah sebagai berikut :

"Anak yang berhadapan dengan hukum adalah anak yang berkonflik dengan hukum, anak yang menjadi korban tindak pidana, dan anak yang menjadi saksi tindak pidana.:

Melihat kecenderungan yang ada di media saat ini, baik media cetak maupun media elektronik, jumlah tindak pidana yang dilakukan oleh anak (juvenile delinquency) semakin meningkat dan semakin beragam modusnya. Masalah delinkuensi anak ini merupakan masalah yang semakin kompleks dan perlu segera diatasi, baik oleh pemerintah maupun masyarakat. Menurut Romli Atmasasmita dalam Wagiati Soetodjo, motivasi intrinsik dan ekstrinsik dari kenakalan anak adalah sebagai berikut :

1. Yang termasuk motivasi intrinsik dari pada kenalan anak-anak adalah:

a. Faktor Intelegentia;

b. Faktor Usia;

c. Faktor Kelamin;

d. Faktor kedudukan anak dalam keluarga.

2. Yang termasuk motivasi ekstrinsik adalah:
a. Aktor rumah tangga;
b. Faktor pendidikan dan sekolah;
c. Faktor pergaulan anak
d. Faktor mass media.

Berbagai faktor tersebut memungkinkan bagi anak untuk melakukan kenakalan dan kegiatan kriminal yang dapat membuat mereka terpaksa berhadapan dengan hukum dan sistem peradilan. Anak yang melakukan tindak pidana ini bisa disebut pula dengan anak yang berhadapan dengan hukum.

Menurut Kartini Kartono (1998:7), pengaruh sosial kultural memainkan peranan yang besar dalam pembentukan atau pengkondisian tingkah laku kriminal anak. Perilaku anak yang terlibat tindak kriminal atau melakukan pelanggaran norma sosial dan hukum menunjukan tanda-tanda kurang atau tidak adanya konfromitas terhadap norma-norma sosial. Kenakalan kejahatan yang terkadang mereka anggap wajar, ternyata tak jarang menyebabkan anak tersebut melakukan tindak kejahatan yang melanggar hukum diusia anak. Sebagai anak yang melakukan pelanggaran atau kejahatan (berkonflik dengan hukum), seringkali hak-hak anak tersebut tidak terlindungi pada setiap fase pemeriksaan, mulai dari proses penidikan yang lazimnya orang dewasa, proses integrasi yang tak jarang diwarnai kekerasan hingga proses persidangan di pengadilan yang tanpa didampingi oleh pengacara, psikolog, maupun pekerja sosial dan tidak mendapatkan advokasi. 


\section{Pekerja Sosial}

Dalam bekerja dengan anak khususnya anak yang berkonflik dengan hukum, seorang pekerja sosial harus melakukan tindakan-tindakan yang profesional dalam artian memiliki pengetahuan dengan latar belakang pendidikan pekerjaan sosial, nilai dalam praktek pekerjaan sosial harus dilandasi oleh kode etik praktek pekerjaan sosial, dan keterampilan seorang pekerja sosial yang dapat menyesuaikan dengan setting pekerjaan sosial.

Profesi pekerjaan sosial mendorong upaya pemecahan masalah dalam hubungan antar manusia, perubahan sosial, pemberdayaan dan pembebasan manusia, dan memperbaiki masyarakat. Menggunakan teori-teori tentang perilaku manusia dan sistem sosial, pekerjaan sosial melakukan intervensi pada pokok interaksi antara manusia dengan lingkungannya. Prinsip-prinsip hak asasi manusia dan keadilan sosial merupakan hal dasar/fundamental bagi pekerjaan sosial. (International Federation of Social Workers (IFSW), 2000).

Pekerja sosial dapat bekerja dengan individu/kelompok kecil untuk membantu bagi perubahan tingkah laku. Berupaya menyesuaikan dengan kehidupan penjara melalui cara pemecahan (coping) masalah seperti kekerasan, serangan seksual, homosexual dan ketergantungan NAPZA. Pekerja sosial juga memberikan pelayanan juga memberikan pelayanan dalam bidang advokasi, pialang, dan mengkaitkan antara individu dengan masyarakat. (Ivanorff Syth \& Finnegan, 1993)

Prinsip hak asasi manusia dan keadilan sosial dapat diartikan membela atau memperjuangkan hak anak yang berhadapan dengan hukum sesuai dengan Undang-Undang Perlindungan Anak dan Sistem Peradilan Pidana Anak berupa advokasi yang merupakan salah satu fungsi representatif pekerja sosial. Dalam pekerjaan sosial, advokasi dilakukan untuk membantu individu, kelompok dan orang yang tidak mampu agar dapat membantu diri mereka sendiri.

\section{Pekerja Sosial sebagai Pendamping}

Pekerja sosial sebagai seorang pendamping anak yang berkonflik dengan hukum harus memiliki kualitas pribadi, baik yang bersumber dari kompetensi profesionalnya maupun yang secara fundamental melekat pada kualitas kepribadiannya. Kualitas pribadi tersebut diperoleh disamping melalui proses pelatihan, terlebih utama diperoleh dari pengalaman praktek dengan anak. Kesadaran untuk membangun dan meningkatkan kualitas kesadaran untuk membangun dan meningkatkan kualitas pribadi pendamping secara terus menerus dikembangkan oleh pendamping itu sendiri dalam rangka tanggung jawab profesionalnya. Beberapa ciri kualitas pendamping masyarakat antara lain (Setiawan,2006) :

a. Kematangan Pribadi

Pada dasarnya individu mengalami perkembangan dan pertumbuhan yang terus menerus kearah kematangan pribadi. Pengalaman baru sebagai acuan perubahan secara tidak langsug akan membentuk pribadi seseorang. Pendamping yang memiliki pribadi yang matang akan mesikapi situasi sebagai fenomena dari suatu proses perubahan yang tidak pernah berhenti berproses.

b. Kreatifitas

Praktek pertolongan yang efektif mencakup pencarian alternatif baru sebagai pemecahan masalah. Kreatifitas pendamping sangat diperlukan untuk menghadapi keterbatasan dalam menemukan dan merumuskan pilihan alternatif pemecahan masalah. Pendamping anak yang berkonflik dengan hukum dimungkinkan tumbuh dari kebutuhannya terhadap pengalaman-pengalaman baru dan rasa keingin tahuan yang tiada henti. Cara yang sudah ada memberikan peluang munculnya pengembangan cara-cara baru. Pendamping yang kreatif akan selalu menjaga keterbukaannya, memelihara perbedaan dan memiliki toleransi yang tinggi terhadap konflik.

c. Pengamatan Diri 
Pengamatan diri diartikan sebagai kemampuan pendamping peka terhadap kondisi internal didalam dirinya. Kemampuan pengamatan diri bagi seorang pendamping anak berhadapan dengan hukum mencakup mencintai diri sendiri sekaligus mencintai orang lain. Dengan demikian kepercayaan, penerimaan, dan keyakinan. Pengamatan diri sendiri secara utuh mengungkap kelemahan/keterbatasan diri disamping kemampuan/kelebihan yang dimiliki.

d. Keinginan Untuk Menolong

Seorang pendamping anak yang berhadapan dengan hukum mutlak harus memiliki keinginan yang kuat untuk menolong orang lain. Keinginan tersebut merupakan komitmen diri ketimbang dorongan dari orang lain. Keinginan tersebut sepenuhnya muncul dari diri pekerja sosial sebagai perwujudan komitmen diri. Komitmen menolong orang lain memerlukan keberanian untuk mengambil resiko terhadap diri pekerja sosial sebagai akibat pertolongan.

e. Keberanian

Seorang pendamping anak yang berkonflik dengan hukum harus memiliki keberanian yang didasari untuk melakukan hal-hal yang dianggap perlu sekaligus kesiapan menanggung segala resiko yang muncul akibat keputusannya. Keberanian menerima kegagalan yang terjadi dari proses pelayanan, terlibat dari berbagai kesulitan dan kekecewaan yang menyertai kegalalan tersebut, situasi dipersalahkan, berada dalam kondisi ketidakpastian dan terancam secara fisik. Keberanian pendamping termasuk menghadapkan anak yang berkonflik dengan hukum dengan realitas masalah yang dihadapinya yang terasa mengancam dan menyakitkan.

f. Kepekaan

Kesulitan utama pendampingan anak yang berkonflik dengan hukum adalah mengenali dan mengemukakan permasalahan, yang utamanya bersumber pada keterlibatan perasaan, kompleksitas masalah dan adaptasi terhadap masalah. Kemampuan empati pendamping akan membantu dalam menemukan, mengenali dan mengemukakan masalah yang sedang dialami anak. Seorang pendamping perlu mengenali perubahan-perubahan kecil apapun yang ada di masyarakat dan mengambil kesimpulan dan makna dari perubahan-perubahan tersebut. Pendampingan harus menjauhkan diri dari sikap generalisasi (stereo type).

\section{PENUTUP}

Pekerja sosial mempunyai keterbatasan-keterbatasan dalam melakukan intervensi terhadap anak yang berkonflik dengan hukum sehingga perlu melibatkan pihak-pihak lain yang mempunyai kewenangan terhadapan anak berhadapan dengan hukum.

Pekerja sosial harus memandang anak berhadapan dengan hukum sebagai korban dan bukan sebagai seorang pelaku. Anak sebagai korban adalah korban dari perlakuan salah orang dewasa karena anak belum mengerti dan dalam proses belajar sehingga perlu pendampingan dari seorang pekerja sosial.

Dalam melakukan pendampingan terhadap anak berhadapan dengan hukum, pekerja sosial harus mendengarkan suara anak dan tidak boleh mendominasi dalam proses pendampingan.

\section{Buku dan Makalah :}

\section{DAFTAR PUSTAKA}

Alit Kurniasari, Studi Penanganan Anak Berkonflik Dengan Hukum, Pusat Penelitian Kementrian Sosial. Diakses pada 5 Desember 2014. http://puslit.kemsos.go.id/upload/post/files/48df6bda92fc77fb5c4407e88859dc5a.pdf 
Anna Volz, Advocacy Strategies Training Manual: General Comment No.10: Children's Rights in Juvenile Justice, Defence for Children International, 2009. Diakses pada 5 Desember 2014.

Marlina, Peradilan Pidana Anak Di Indonesia Pengembangan Konsep Diversi dan Restorative Justice, Refki Aditama, Bandung, 2009, hlm. 34-35.

Lilik Mulyadi, 2005. Putusan Hakim Dalam Hukum Acara Pidana,Bandung, PT. Cipta Aditya Bakti. Hal. 16-17.

Soetodjo, Wagiati, 2006. Hukum Pidana Anak. Bandung, PT. Refika Aditama. Hal. 17.

Yayasan Pemantau Hak Anak, Anak yang Berhadapan dengan Hukum dalam Perspektif Hukum Hak Asasi Manusia Internasional, hal 1. Diakses pada 5 Desember 2014.

Sumber UU:

Konvensi dan Undang- Undang :

Undang-Undang No. 23 Tahun 2002 Tentang Perlindungan Anak.

Undang-Undang No. 4 Tahun 1979 Tentang Kesejahteraan Anak.

Undang-Undang No. 11 Tahun 2012 tentang Sistem Peradilan Pidana. 